\title{
The Tar and Nicotine Tax: Pursuing Public Health Through Tax Incentives*
}

\author{
William Drayton, Jr. $†$
}

Government's increasing efforts to discourage cigarette smoking over the last decade have generally failed. 1 Warnings about smoking, and tax increases which raise all cigarette prices, harry the habitual smoker but do not make him stop. In order to change smoking patterns, government must first modify its strategy. Rather than attempting to diminish total cigarette consumption, it should focus on the more attainable goal of reducing the harmfulness of what is smoked. Tobacco manufacturers could lower tar and nicotine levels greatly; smokers that can't quit can switch.

A special tax on cigarette brands high in tar and nicotine would be an effective means of executing this strategy. Such a tax would encourage the consumption of lower tar and nicotine brands by making them less expensive for the consumer and/or more profitable for the manufacturer. The tax can also be an efficient source of public revenues. New York City has had such a tax in effect since July 1, 1971;? its success in meeting both the city's public health and revenue objectives suggests that New York's lead may well be followed by other governments, local, state, and national. ${ }^{3}$

* The opinions and analyses set forth in this article are the author's sole responsibility and should not be taken to express the viewpoint of the firm of Mickinsey \& Company, Inc.

$t$ Associate, Mfckinsey \& Company, New York; A.B. 1965 Harvard College; M.A. 1967 Oxford University; J.D. 1970 Yale University; Member New York Bar.

1. See p. 1490.

2. Under the New York program, cigarettes with 17 milligrams of tar and 1.1 milligrams of nicotine or less are tax-frec; those exceeding both standards are taxed at four cents a pack. Thus, according to the tar and nicotine measurements of the Federal Trade Commission in August, 1971, Winstons are taxed at four cents while losier tar and nicotine Dorals are not taxed at all. These rates were merely added to the city's existing four-cents-a-pack, general cigarette tax, in order not to lose revenue or reduce whatever deterrent effect the high flat-rate tax has. Tar and Nicotine Ordinance, Local Law 34, 5 NEw YoRK CITY, N.Y. AdMr. CODE \$ D46.80 (Supp. 1971).

Administratively the tar and nicotine tax simply "piggy-backs" the traditional flatrate tax mechanism. Both are collected simultaneously at the wholesale level through the sale of required tax stamps, and policing one automatically enforces the other. Thic New York tax applies only to cigarettes, not cigars or manufactured tobacco. Id.

3. The idea of varying cigarette taxes with the hamful components in cigarette smoke is a simple, almost obvious reform that has been proposed, apparently independently, several times prior to New York's consideration of the idea. On September 12, 1967, Senator Robert Kennedy proposed such a tax nationally. Letter from Dr. Daniel Horn, National Clearinghouse for Smoking and Health, U.S. Public Health Service, to Mayor John V. Lindsay, May 27, 197i, replying to a request from the Mayor for comments on the proposed New York tax. In December 1970, Representative John Busienger introduced a bill in the Massachusetts legislature that vould authorize 
This article seeks to define and evaluate the tar and nicotine tax alternative. First, it explains why government must switch to a tar and nicotine tax strategy if it is to have a significant impact on smoking. Second, it evaluates the effectiveness of such a tax, both in theory, and in the light of New York's experience. ${ }^{4}$ Finally, it explains the structure that would give the tax the greatest possible impact.

\section{The Need for a New Strategy Against Smoking: Taxation of Tar and Nicotine Content}

The extensive research done on cigarettes during the last decade has convinced the medical profession and appropriate government agencies $^{5}$ that cigarette smoking is a major cause of disability and death. In the United States, over fifty medical associations have officially sought to discourage smoking. ${ }^{.}$In the United Kingclom, the Royal College of Physicians has announced that illnesses caused by smoking have reached "epidemic proportions" requiring a strong preventive response. ${ }^{7}$

a master plan for taxation to include the study of relating the state cigarctte tax to tar and nicotine content. Interviews with the Clerk of the Massachusetts Honse and Mr. Ronald F. Rosenblith, aide to Representative Busienger, February 1971. Recently at the federal level, Senator Frank Moss has introduced a bill that would establish a national tar and nicotine tax. N.X. Times, Jan. 16, 1972, $\$ 3$ (Business and Finance), at $F$, col. 1. U.S. Surgeon General Jesse L. Steinfeld, in reporting that the Nixon $\Lambda$ diministration is considering a series of new initiatives to reduce the hazards of cigarette smoking, specifically suggested levying such a tax. The Wall Street J., Jan. 11, 1972, at 5, col. 2.

4. Much of the data and analyses used in this article was originally undertaken by the author as part of the McKinsey \& Company staff working for the Bureall of the Budget of the City of New York to analyze alternative means of increasing city tax reventies. Filic study initially weighed a wide range of alternative tobacco taxes. The author is in. debted to the city for releasing this material for use in the preparation of this article, and to his colleagues at McKinsey, notably Gerald P. Hillman, for their help and criti. cal comments.

5. These authorities include the President's Commission on Heart Discases, Canccr, and Stroke; the U.S. Surgeon General, and the U.S. Public Health Scrvicc.

The U.S. Federal Trade Commission has officially recommended to the Congress that the warning label now required on all cigarette packs be amended to read: "Warning: Cigarette smoking is dangerous to your health and may cause death from cancer, coronary heart disease, chronic bronchitis, pulmonary emphysema, and other discases." FevekAl. Trade Comm'n, ANnual Report: 1969 at 11 (1969). The Federal Communications Coinmission has held that it is no longer a controversial issue "that cigarette smoking is a hazard to public health (i.e., the main cause of lung cancer; the most inportant caluse of chronic bronchitis or pulmonary emphysema, etc.)." 35 Fed. Reg. 19282, 19283 (197(0) A compilation listing the various authorities alleging a relationship between the cle. ments of tobacco smoke and disease, part of the original Mckinscy study prepared for New York City, is also on file with the Yale Law Journal.

6. A partial list includes: American Association for Cancer Research; Ancrican $\Lambda$ s. sociation for Thoracic Surgery; American Cancer Society; American Collegc of Chest Physicians; American College Health Association; American College of Physicians; Amerl. can Heart Association; American Medical Association; and the medical associations of California, New York, and Pennsylvania.

7. "Premature deaths and disabling illnesses caused by cigarcttc smoking have now reached epidemic proportions and present the most challenging of all opportunitics for 
Whether or not the state should intervene to limit the costs of smoking to the individual and society, ${ }^{8}$ and to what degree, ultimately remain, of course, political issues that each community must decide. ${ }^{2}$ However, it is clear that the trend of public policy is toward more vigorous and determined intervention. Traditional flat rate cigarette taxes, which have long been justified in part as a means of discouraging cigarette consumption, have now been imposed separately by over 272 communities, by all fifty states, and by the federal government. ${ }^{10}$ During the last decade, their rates have risen rapid. ly. Moreover, government has supplemented flat rate taxation with a campaign of persuasion ${ }^{11}$ and the prohibition of broadcast cigarette advertising. ${ }^{12}$

preventive medicine in this country." Royar College of Puysichass, SMoking aNd HEALTH Now 1 (1971). In January 1972, the U.S. Surgeon General concurred:

I can think of no bigger public health hazard about which we know and can do something [than smoking].

Wall Street J., Jan. 11, 1972, at 5, col. 2.

8. Smoking's external costs include discomfort and danger to others. See note 24 infra. Smoking also causes increased welfare and public hospital expenses, heary lorest damage from cigarette fires, and higher auto accident rates. H. DiEm, Touscco AND Your Health: The Smoking CoNtroversy 108, 198, 200, 201 (1969). National AdvisonY CANCER Councir, Progress Aganst CANCER 1970, at 42; Speer, Tobacco and the Nonsmoher: A Study of Subjective Symploms, 16 Arcir. Envirosmertal Healtu 443 (1968). Alluough the association between smoking and work loss and hospitalization seems firmly es. tablished (see DreHL, id. at 198), exact percentages are less certain given the ambiguity in diagnosing many diseases as well as the problems of case sampling. National pro. ductivity may suffer also from smoking. In Britain as many as ffty million working days may be lost every year as a consequence of cigarette smoking. ROyAL ColLEGE of Physicians, SMOKing aNd Healti Now, supra note 7 , at 33.

9. Although intervention to protect the public health has long been an aecepied government function, doing so in the case of smoking is challenged by the industry and some conservatives as an infringement of the citizens' freclom. While insuring a clean and safe water supply is beyond the power of individual citizens and requires joint action, it is argued that each person is-and should continue to be-free to choose whether or not to smoke.

There are two counterarguments to this anti-interventionist position. The first is that the individual is no longer free to choose once he has begun to smoke and has become habituated. This argument is reinforced by the fact that most people who start to smoke do so when they are young.

The second counterargument is that the illness, disability, and premature death linked to tobacco are harmful and costly to society as well as the individual vietim and thus justify government intervention. See note 8 supra.

Whether or not the smoker who creates these costs is able to stop at will, tue considerable costs he imposes on society by not doing so justify government intervention, if only to limit the costs and/or to seck compensation.

10. Tobacco Tax Council, Inc., The Tax Burden on Todacco: Historacal CospILATION 79 (1971). New York's new tar and nicotine tax is another clear indication of the developing trend of legislative intent against smoking.

11. Led by the Surgeon General and the Public Health Service, the government issued repeated warnings to the public. It caused warnings to be broadcast in reply to cigarette advertisements under the authority of the FCC's equal-time doctrine, and it forced cigarette manufacturers to print warnings on each pack sold.

12. Effective January, 1971 , cigarette advertisements were banned from the broadcast media. Wash. Post, Jan. 1, 1971, § B, at 1, col. 1 . 
These methods have been generally ineffective. ${ }^{13}$ The imposition of even very stiff flat-rate taxes seems to reduce sales only slightly and temporarily. ${ }^{14}$ Even the high tax rate applied to cigarettes in Eng. land, over fifty per cent more than United States' levels, has failed to reduce total consumption significantly. ${ }^{15}$ Despite the new prohibition on broadcast advertising, cigarette sales increased between 1.5 and 3.0 per cent during $1971 .{ }^{16}$ The combined impact of these traditional means of discouraging smoking has not been great: The average per capita consumption of cigarettes in 1971 was only sixteen cigarettes less than in 1961-a reduction of less than seven-tenths of one per cent. ${ }^{17}$

The health impact of this seven-tenths of one per cent reduction has, moreover, been cancelled by an increase in the amount of tar and nicotine delivered by the average cigarette. ${ }^{18}$ The amount of tar and nicotine consumed increases with the length of the cigarette, and cigarettes have been getting longer: The one-hundred millimeter cigarettes, which had captured eighteen per cent of the national market by 1970, are gaining ground year by year. ${ }^{10}$ Further, some manufacturers

13. High cigarette taxes and publicized warnings probably limit the harm done by smoking to some degree by discouraging some potential smokers from beginning and by encouraging a few smokers to switch from cigarettes to relatively less harmful cigar and pipe smoking. All the efforts against smoking have in fact catsed the manufacturers to respond to the health issue by catering to the market for lower tar and nicotinc brands. Manufacturers certainly know the value of advertising low tar and nicotinc content. The Philip Morris Company introduced a new "lowered tar and nicotine" variant on its leading Marlboro brand, called "Marlboro Lights," just after New York passed its tar and nicotine tax.

14. An analysis of increases in the traditional flat-rate cigarette tax in New York, New York State, and five neighboring states during the last ten years reveals a small decrease in the number of packs taxed per capita shortly after most increases in the tax rates. AIcKinsey Study, part of the data and analyses prepared for New York Cilty, on file with the Yale Law Journal. However, probably only part of that decrase cail be explained by the deterrent to sales of post-tax price increases and the publicity about the health implications of smoking ustually associated with such increases. Becausc of the relatively high tax rates of the Northeastern states studied, each new increase would encourage smuggling as well as discourage smoking. In any case, the disincentive effect suggested by the figures is much smaller than that sought by public health officials.

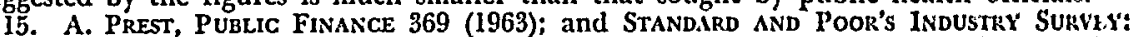
Товассо 108 (1970). However, Gcorge Weissman, president of l'hilip Morris, Inc. Mas stated that he considered flat-rate taxes "a very present and severe threat to salcs." N.Y. Times, Jan. 16, 1972, $\$ 3$ (Business and Finance), at 7 , col. 1 .

16. Business WEEK, Dec. 25, 1971, at 56; N.Y. Times, Jan. 16, 1972, $\$ 3$ (Business and Finance), at 7, col. 2; Wall Street J., Jan. 17, 1972, at 30, col. 2. The prohibition on cigarette broadcasts of course also ended the "equal time" previously made available for warnings about the health consequences of smoking. The net effect of this chatigc may have been to reduce the public's concern about cigarettes.

17. ToBAcco TAx Council, supra note 10 , at 6 .

18. In 1971 the average cigarette, taking sales volume into account, had the same tar level as 1970 , but an increase from 1.3 to 1.4 milligrams of nicotine (in a range of 1.0 to 1.8) per cigarette relative to 1970. Federal Trade Comin's, The Tar and Nicotinl: Content of Cigaretres, April, 1972; Maxwell, Cigarette Scorebox, BAkkons, Nov، 2, 1972 , at 11 .

19. Maxwell, supra note 18. Sales of one hundred millimeter filtercd cigarettes ad. vanced seven per cent in 1971, the industry's greatest gain. BusINESS WEEK, supra note 
have recently marketed brands with filters which are likely to make the consumer feel relatively safe, but which are supposed to give greater "satisfaction" by using unusually high tar and nicotine levels."

Thus, despite the government's efforts, the health situation has not improved. This is because the government's interventions have all shared the common, unrealistic goal of reducing total cigarette consumption. Legislators and public officials must learn from these past experiences: Most smokers cannot or will not quit.

Given a realistic recognition that aggregate demand for cigarettes is highly inelastic, governments seeking to minimize the harm done by smoking should consider adopting the tried strategy of the old British Empire: Divide and Rule. Government intervention designed to reduce the danger of cigarettes by discouraging the production and sale of the most harmful brands should succeed where intervention designed to cut total sales has failed. The divide and rule strategy would then be to direct consumption away from particular brands, rather than away from cigarettes generally. The impact of such a plan depends on government's ability to isolate the harmful elements in cigarettes, the manufacturers' technical ability to reduce those elements significantly, and the legislature's selection of an effective mechanism for implementing the strategy.

The cigarette components that government intervention should fo-

16. This general trend is desirable from the industry's viewpoint because cach increase in length means an increase in sales, given the fact that smokers tend not to reduce the number of cigarettes they smoke, even though each one is longer and more cxpensive. Moreover, smokers of king-sized and 100 millimeter cigaretics tend to smoke their cigarettes as close to the butt as do smokers of regular cigarettes. Moore, Bross, Shamberger \& Bock, Tar and Nicotine Removal From Fifly-Six Brands of Cigarelles, 20 CANCER 323, 331 (1967). These longer cigarettes, therefore, induce the smoker to

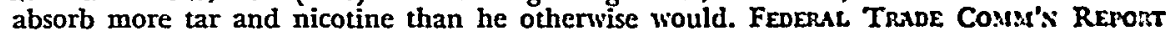
To CoNGRES: 1969, at 16-17 (1969); telephone interview with Dr. D. Schoplind of the U.S. Public Health Service, Feb., 1971.

Generally, king-sized cigarettes have higher tar and nicotine levels than regulars and the new 100 millimeter cigarettes have even higher levels. One part of the data and analyses prepared by Mckinsey for New York City, on file with the Yale Law Joumal. This study is confirmed by earlier United States' and Canadian studies using independent measurements. Forbes, Robinson \& Stanton, Tar and Nicotine Retrictal From Cigarelles Available in Canada, 23 CANCER 910 (1969).

20. Although in general filtered cigarette smoke has lower tar and nicotine content than unfiltered smoke, some cigarettes have only token filters and others are made from low-grade tobacco (high in tar and nicotinc) so that despite the filter the smoker receives a highly dangerous dose. The filter thus engenders a false sense of safety. For example, only four cigarette brands (all nonfilter) out of 121 varieties tested by the Federal Trade Commission in August, 1971, had a higher tar content than the Amcrican Brands Company's Bull Durham, a filter cigarette. Only three had a higher nicotine count. Other filter cigarettes with particularly high tar and nicotine contents include old Gold, Marlboro, and Winston. The United States Public Health Service's National Advisory Cancer Council recommended in 1970 that "a trend noted in some of the more recently introduced filter cigarettes, designed for increased 'satisfaction' and re. sulting in higher "tar' and nicotine yields, should be reversed." Natrovat Abrisonr CANCER Council Report, supta note 8, at 56. 
cus on are tar and nicotine. Medical research now accepted as the basis of government policy indicates that they cause most of the dam. age done by cigarette smoke, ${ }^{21}$ that the danger of smoking is roughly proportional to the amount of tar and nicotine ingested 22 and that tar and nicotine levels vary widely from brand to brand. ${ }^{20}$ There are, of course, other harmful substances in cigarette smoke, notably carbon monoxide, ${ }^{24}$ but tying tax liability to any of them would create serious administrative problems. Determining proper standards would be difficult, given existing research knowledge; collection and cnforcement would be burdened with complicated testing requirements, since at present the Federal Trade Commission regularly measures only tar and nicotine levels. ${ }^{25}$ In any case, reducing tar levels will diminish most of these other substances as well.20 Smokers will not negate the health advantage gained from lower levels of tar and nico. tine by smoking more cigarettes, or smoking the same number morc deeply. ${ }^{27}$

21. A compilation of the alleged links between various diseases and the components of cigarette smoke, on file with the Yale Law Journal, originally onc part of the data and analyses prepared by McKinsey for New York City.

22. In the words of a committee reporting to the U.S. Surgcon Gencral: "The pres ponderance of scientific evidence strongly suggests that the lower tar and nicotinc content of cigarette smoke, the less harmful are the effects." Hearings on H.R. 643, 1237, 3055, 65+3, and Similar Bills Before the Committee on Interstate and Forcign Gom. merce, 91st Cong., 1st Sess., ser. 91-11, pt. 2, at 455 (1969).

23. See Hammond, Smoking in Relation to Physical Complaints, 3 Akcil. ENvik. HEALTH 146 (1961); Wynder \& Hoffman, Reduction of Tumorigenicity of Cigarclla Smoke: An Experimental Approach, 192 J. Am. MEDICAL Ass'N 88 (1965); Bock, Muorc \& Clark, Carcinogenic Activity of Cigarette Smoke Condensate, 34 J. NAT'L CuNCEk INSI. $481-93$ (1965); Forbes, Robinson \& Stanton, supra note 19, at 910 (1969); Moore, Bross, Shamberger \& Bock, supra note 19, at 323 (1967).

24. For example, the level of carbon monoxide in cigarcttc smokc, which displaccs essential oxygen in the blood's hemoglobin, has been linked to arteriosclerosis, coronary heart disease, and temporary mental slowing. Public Henlti SEkvice, U.S. De't OF Health, Ed. \& Welfare, The Health Consequences of Smoking: a Reporr of thil SuRgeon General 62.63 (1972). The other elements, long listed in this category, are tar and nicotine. Not only was the classic smoke-filled room (or automobile) reported to be dangerous to those with heart or respiratory diseases, but, according to soine tests, the level of carbon monoxide introduced into a twelve by fourteen foot room after one pack of cigarettes had been smoked was also sufficient to reduce the auditory dis. crimination, visual acuity, and ability to distinguish the relative brightness of lights of completely' healthy adults. Inhalation of carbon monoxide can be reduced by charcoal filters which are, however, largely ineffective in reducing tar and nicotinc. polynucleatr aromatic hydrocarbons in tar, many of which are considered carcinogenic, could also be reduced. RePORT of tHe SURGEON GENERAL 280 (1971); Wynder \& Hoffinan, Livpcri. mental Tobacco Carcinogenesis, 162 ScIEnce 862 (1968).

25. Moreover, the F.T.C. has sought and won a voluntary agrccment from most manufacturers to print the F.T.C.-measured tar and nicotine content of each type and brand of cigarette. Hearings, supra note 22, at 455, 458, and pt. 1, at 87; Federul Thuve: Comm'n, Report to Congress pursunint to the public Healtil Cignkette Smoking Acit, December 1967 and 1970.

26. Gases such as carbon monoxide are, of course, not part of the smoke's particulate content. However, a reduction in tar and nicotine correlates with a reduction in carbon monoxide. Telephone interview with Mr. Emil Corwin, National Clearing Housc on Smoking and Health, U.S. Public Health Service, Fcb. 18, 1972.

27. It has been shown that the number of cigarettes smoked, how completely cach is smoked, and how deeply the smoke is inhaled are stable habits. Dient, supra note 8 , 
Moreover, the cigarette industry is in a position to reduce tar and nicotine levels significantly and quickly through a variety of techniques. Manufacturers could use more high quality tobaccos, which are more expensive but have lower tar and nicotine contents. With minimal expense, they could employ more highly porous paper and tobacco cuts designed for more complete burning, nitrate additives to reduce the carcinogenic polynuclear aromatic hydrocarbon portion of tar, shredded reconstituted tobacco sheet, and a greater proportion of low-tar stems. They could utilize more effective filters; ${ }^{28}$ and by freeze-drying the tobacco, they could reduce tar and nicotine levels by more than half. ${ }^{29}$ In sum, the presence of low tar and nicotine brands already on the market indicates that no significant technical or economic barriers to safer cigarettes exist.

Having isolated tar and nicotine content as the best target for a divide and rule strategy, the need for an effective mechanism to implement the strategy remains. There are two possibilities: taxation and/or selective prohibition of the most dangerous brands..$^{30}$

Unlike prohibition, taxation works at the margin: The new smoker is much less likely to pay premium prices or go to the inconvenience of obtaining bootlegged brands than a committed smoker with a firm belief that his brand fits his personality and "taste." Both measures

at 202; Moore, Bross, Shamberger \& Bock, supra note 19, at 323, 331; cf. TIME MIAnsETING RESEARCH REPORT No. 1606 (1970). There is still some controversy as to whether the cigarette smoker's "need" for nicotine is physiological or psychological. Telcphone interview with Mr. Emil Corwin, National Clearinghouse for Smoking and Health, US. Public Health Service, Feb., 1971. See also RoYAl College, supra note 8, at 112.13. Probably the most dramatic proof that the number of cigarettes smoked is not depend. ent on tar and nicotine levels came with the introduction and rapid popular acceptance of filters. Filters led to a sharp decrease in avcrage tar and nicotinc consumption. However, per capita cigarette consumption did not increase in that decade; it leveled off. Tobacco Tax Council, Inc., The Tax Bunden on Tobacco 3 (1970). It therefore secms safe to assume that reducing tar and nicotine content per cigarette vould result in less tar and nicotine consumption, not more.

28. Nat'l Advisory Cancer Council Report, supra note 8, at 55, 56; Mloore at al., supra note 19; Wynder \& Hoffman, supra note 23; cf. Moshy, 162 Tosacco 22 (1960).

29. Statement of Professor W.H. Johnson, Department of Biological and Agrieultural Engineering, North Carolina State University, Hearings, supro note 22, pt. 3, at $1368-71$. Cigarette manufacturers interviewed reported that the method is not now in use. However, Professor W.H. Johnson of North Carolina State University reports that R.J. Reynolds is experimenting with another method of modifying tobacco structure known as "puffing" which would also reduce tar and nicotine content per eigarette by in. creasing volume. Dr. Johnson further reports that tests are now being conducted on the use of a volume-expanding foaming agent for reconstituted sheet tobacco that would achieve the same effect. Telephone interviews with Professor W.H. Johnson, and officials and technicians of several major cigarcte companics in February, 1971.

30. Prohibiting smoking altogether would suffer from the same fundamental veakness as past measures. Many, perhaps most smokers, would find their habit driving them to break the law. Unless the federal government were willing and able to mouni a massive, uncorruptible enforcement effort, large-scale, high-priced smuggling vould result. Given the difficulty of preventing such smuggling, the poster of the cigarette industry, the degree to which governments have come to depend on tobaceo tax revenues, and the country's experience with the Eighteenth Amendment, total prohibition is not a realistic option. 
are likely to be effective because the course of action they ask cigarette consumers and manufacturers to follow-switching to low tar and nico. tine cigarettes-is a very much easier, more acceptable path than that of giving up cigarettes entirely. Its acceptability is further enhanced because the firms that do switch are rewarded with a larger share of the market. Their total profits would also be greater, assuming the effect of larger sales volume outweighed the costs of measures necessary to reduce tar and nicotine levels. Both measures would aid those most in need: the smoker unable to stop and the millions who start smoking each year regardless of health admonitions. However, taxation is much the more likely immediate approach as it is a less drastic intervention, will raise revenue as well as serve the government's public health objectives, and can be applied to most cigarettes without creating the potential smuggling problems of selective prohibition. ${ }^{31}$

\section{An Evaluation of the Tar and Nicotine Tax}

A tar and nicotine tax should be analyzed in terms of five criteria: its efficiency as a form of intervention, its effectiveness as a public health measure, its value as a revenue source, its ease of administration, and its equity.

\section{A. The Tar and Nicotine Tax as an Incentive Tax}

A tar and nicotine tax is a simple example of an incentive taxa tax designed in part to alter pre-existing market conditions, usually by discouraging one type of purchase or course of action as against competing alternatives. A familiar example is the use of tariffs to discourage foreign imports. Since every tax causes some change, and since the relevant interest groups and therefore the legislatures are usually very much aware of such effects, every tax can, strictly speaking, be said to have some incentive effects. It is the degree of the intended effect of the tax in inducing such change that indicates how much of an incentive tax it is. However, most taxes, including the sumptuary

31. Even highly selective prohibition would probably creatc some smuggling unless enforced at the national level. However, should the tax act too slowly or prove in. adequate alone, selective prohibition remains a reasonable supplementary step for the national government to consider. Its impact would be instantancous and unambiguous. Combining selective prohibition of the most dangerous brands with a tar and nfcotinc tax would not reduce the tax's revenues greatly since most smokers of the prohibited brands would theoretically switch rather than quit. 
excise taxes on tobacco and alcohol, ${ }^{32}$ are passed for, and in fact primarily serve, other purposes. ${ }^{33}$

Incentive taxes are a powerful and efficient regulatory tool which government can be expected to use increasingly. ${ }^{3 t}$ They are likely to be effective primarily because they exploit potent competitive market forces. A well-designed incentive tax changes the profitability and market position of any one manufacturer relative to his competitors. A cigarette manufacturer who lags behind in shifting to low tar and nicotine brands and is therefore subject to taxes which absorb a substantial portion of his normal per pack profit margin; will feel an unmistakable, sharp pressure to bring his products beneath the tax's cut-off points. In a competitive situation his only alternative to paying his profits over to the public treasury will be to lose a part of his market share. Thus, the tar and nicotine tax magnifies the power of its im-

32. Some sumptuary excise taxes are affixed according to the undesirable element in the commodity, such as the alcoholic content of wine. Distilled spirits or wine above twenty-four per cent of absolute alcohol by volume are taxed at a rate of $\$ 1050$ on each proof gallon. 26 U.S.C. $\$ 5001$ (1970). Differential rates are applied to wines: those with less than fourteen per cent of alcohol by volume, generally table vine, are taxed seventeen cents per wine gallon; those with between fourteen and twenty-one per cent are taxed sixty-seven cents per wine gallon; and those with between twenty-one and twenty-four per cent, generally port or sherry, are taxed $\$ 2.25$ per wine gallon. 26 U.S.C. $\$ 5041$ (1970). Beer is taxed at a rate of $\$ 9.00$ per thirty-one gallon barrel. 20 US.C. $\$ 5051$ (1970). If beer were taxed at the distilled spirits rate, the amount duc would be \$26.04. Despite the apparent parallel with the tar and nicotine tax, these taxes are not perceived as incentive taxes designed to reduce consumption. The higher rates for higher proof drinks are defended instead primarily on the grounds of progressivity. Moreover, there is a great deal of difference between becr and scotch, table wine and sherry-much more so than between Winstons and Marlboros. This difference substantially reduces the potential effectiveness of a tax designed to cause switching by creating price differences. Nonetheless, the differences that do exist may in fact encourage some marginal switching from distilled spirits to "the poor man's drink," beer.

33. See J. Due, Indirect Taxation in Developinc EcoNomies 63.64 (1970); Staff of the Joint Economic Comm., 88th CoNG., 20 Sess., The Federal Tax Systear: Facts aNd Problears 150 (1964).

34. Incentive taxes allow the government to intervene in many arcas of production and consumption without assuming the burdens of operating the production enterprise. Government operations are often classic monopolies, either because competition is legally prohibited (as with the police) or because the services provided are at prices well below cost (as with sanitation or health services). Such monopolies have become inefficient and unresponsive; the task is now to create a government that can provide essential services, police the market economy, reallocate resources, and set social priorities, through more effective, responsive, and efficient mechanisms.

Taxation is but one of several means by which government an amend the existing market situation through incentive devices. Government could ensure that adequate resources are given to those whom it wishes to target for specific services by issuing chits or vouchers redeemable in cash by any qualified and licensed person who provides the specified service. For services like sanitation, government could act as a bargaining agent representing its citizen constituency in awarding short-term franchises to independent contractors and then policing and evaluating their performanec. Government bounties could be paid directly to those who have done something the state wants done, and could be used, for example, to replace the corruptible police monopoly at least in areas like white-collar law enforcement. Incentive taxes are thus negative bounties penalizing those who fail to do what the government vants. 
pact by pitting the high tar brands against all others. ${ }^{35}$ Moreover, because government has a vital interest in tax revenues, the use of taxes as a means of public policy intervention leaves much less chance that the intervention will not be enforced than is often the case with other forms of regulation.

Not only can an incentive tax work, it is likely to do so quite efficiently. Its primary enforcer is the market mechanism, not a clumsy and costly bureaucracy. Government merely creates the incentive; the decision of whether or not the advantages of meeting the incentive standards justify the cost of change remain with those most familiar with the facts and most interested in making a correct decision-the affected producers and consumers. In other words, government does what it is best suited to do, determine public policy and priorities, leaving producers and consumers free to make specific production and consumption decisions. If they do not respond as the legislature intended, government can easily and quickly change the direction and/or the degree of pressure behind each incentive.

Incentive taxes not only work through, but may actually improve, the functioning of the market. ${ }^{36}$ If a government is seeking to force some change, such as lowering the tar and nicotine content of cigarettes, it probably feels the change is justified by societal costs, whether or not the costs can be accurately measured. An incentive tax is thus a rough user charge, a price representing the costs of an unsatisfactory

35. Moreover, since companies already satisfying the standards set for tax exemption, and/or those relatively close to meeting the standards would benefit from such il dif. ferential tax, opposition from the industries to be taxed might be less than what onc would otherwise expect. The opposition to a new incentive tax, however, is likely to be more vigorous than is the case with more traditional across-the-board taxes-c'b4, excise and sales taxes. This is so because an effective incentive tax will force uncoin. fortable changes on an industry of usually politically well-organized companics, whercas the traditional flat-rate in the end affects only consumer prices. Althotigh the impact of a tar and nicotine tax would vary a great deal from company to company, no industry source has yet supported such a tax.

36. Some reformers have, however, long argued that the current flat-rate tax on cigarettes should be replaced by an ad valorem tax on the grounds that the flat-rate tax contributes significantly to the oligopolistic structure and lack of price competition in the industry by bearing down proportionately more heavily on any low.priced ciga. rette. See Robertson, Concentration in the Tobacco Industry as Affected by Tax Policic's in Taxation \& Business Concentration, (The Tax Institute cd. 1950). See also N. Shillinc, Excise Taxation of Monopoly 225.30 (1969). A tar and nicotinc tax would run afoul of this argument because it differentiates according to the degree to which a cigarette endangers the public health and not according to price. However, price competition in the cigarette industry is undesirable from the perspective of public health policy. Government almost certainly does not wish to induce new companies into the industry or to foster the aggressive competition or price-cutting that would result. Its intent seems clearly to be to discourage smoking, not vice versa. l'rice competition would be especially harmful from a health point of view: Becausc high tar and nicotine tobacco is relatively inexpensive, it would probably be preferred by manufacturers of low-priced cigarettes. 
condition ${ }^{37}$ Adding such charges to the economic calculations of producers and consumers will force them to recognize more fully the true costs and benefits of their decisions.

Though neither government regulation nor taxation is now considered dangerously unorthodox, incentive taxation sometimes is. Often this fear is due to a misapplication of the concept of tax "ncutrality," the view that a "good" tax, while raising revenue, does not disrupt existing, presumably optimal competitive relationships. Incentive taxcs are in this sense clearly not neutral. However, their intentional effort to alter the status quo may well constitute a refinement, not a disruption of the market. Moreover, as controlled "disruption" is the raison d'etre of an incentive tax, such a tax should be measured against the traditional test of neutrality only to see whether it creates any unintended market change.

\section{B. The Tar and Nicotine Tax as a Public Health Measure}

That incentive taxes are a generally effective form of public intervention does not guarantee, of course, the effectiveness of the tar and nicotine tax specifically. However, an analysis of market economics suggests that the tax will succeed in diminishing tar and nicotine consumption. Cigarette manufacturers, distributors, and retailers could respond to a tar and nicotine tax in three ways: (1) they could pass on all or part of the tax on high tar and nicotine brands to the customer through higher prices; (2) they could absorb the taxes; or (3) they could increase prices of all brands and thus distribute the cost of the tax to smokers of all brands. In all probability the industry will respond, as it did in New York, in a combination of all three ways. State and local taxes have to be collected from numerous local vendors, each of whom will decide which response best suits his circumstances. Even a federal tax collected from the manufacturer would still leave these dealers free to choose whether and in what manner to pass on increased prices from the manufacturers. ${ }^{38}$

To the extent that the tax is borne by the consumer, with high tar and nicotine brands clearly identified by a higher price, both consumers and manufacturers should be pushed toward lower tar and

37. The costs of the smoking-related illnesses and premature death cannot of course be quantified. Even if exact charges could be calculated, auministrative limitations would probably not allow as many rate distinctions between the different goods in any" taxed class as the differences in the so imposed costs would justify.

38. Some retailers now pass on the slightly higher wholesale price for "100" cigarettes while others do not. 
nicotine brands. Consumers are apt to wonder about paying higher prices for products thereby labelled as more dangerous, and each purchase should make them wonder and worry anew. Manufacturers with low tar and nicotine brands will gain market share as consumer preference shifts as a result of this concern. New product introduction and promotional efforts ${ }^{30}$ aimed at this growing part of the mar* ket $^{40}$ will encourage even more consumer switching. ${ }^{41}$ Thus, a benign cycle of consumers and vendors reinforcing each other's moves towards low tar and nicotine cigarettes should result.

The industry's second possible response is to keep prices, and the price relationship between different brands, unchanged by absorbing the tax. ${ }^{42}$ There is a point at which this option becomes economically impossible-and the industry's willingness to absorb will undoubtedly stop long before this point, except perhaps as a short-term tactic designed to discredit the tax. ${ }^{43}$ Given typical margins, the manufacturers cannot absorb more than four cents a pack without losing all profit on the brand taxed. ${ }^{44}$ Absorption is more likely when the tax is small

39. Distributors and retailers may also favor brands that give them a better profit margin by, for example, giving them the best display positions and more columns in the vending machines.

40. Promotional efforts may succeed if one assumes that preference for any one brand of cigarette is primarily, if not exclusively, based on something that goes on it the mind rather than in the body. See Robertson, supra note 36 , at 33 .

41. However, even if a tar and nicotine tax were reflected in varying retail prices, some consumers, attempting to assess the relative hazards of different cigarettes, might be confused if they depended on price distinctions alone. $A$ tar and nicotinc tax with three different rates-like New York's 0,3 and 4 cents a pack-could lead cach retaller to sell cigarettes at as many as six different prices, with up to three prices for regular and king-size brands of varied tar and nicotine content and three prices for the gen. erally higher-priced 100 millimeter brands. Possibly some relatively safe 100 millimeter cigarettes would be selling for more than shorter cigarettes with higher tar and nicotine Ievels. However, the probability of this confusion occurring is limited: Not all retailers maintain the small price differential for 100 millimeter brands, and the 100 's generally have higher tar and nicotine levels.

Some confusion might also occur because prices will vary from retailer to retailer (because of differences in overhead, competition, the use of tobacco as a central or attraction item, etc.). Consequently, even with retail prices that fully reflect the tax's differentials, a low tar and nicotine cigarette may have a higher price when retailed by Store A than a high tar and nicotine cigarette retailed by Store B. This risk would, of course, decline rapidly as the differential between taxed and excmpt cigarettes increased.

Fortunately, these problems are more apparent than real. Consumers who buy only one brand will not be affected. Other consumers are unlikely to be misled by markups that vary from store to store, as such variation does not affect the price differences between brands at any particular outlet.

42. For example, retail tobacconists may attempt to maintain the current simple onc and two price structure, with higher prices in some outlets for 100 millimeter cigarettes, especially where they must sell large volumes quickly such as at concessions in athletlo stadiums or railroad stations. This has clearly been the case in New York. The size of the tax will be a major factor in these decisions: A few cents per pack can obviously be more easily absorbed than a dime. See pp. 1505-06.

43. In 1933, the major cigarette manufacturers cut their prices forty per cent to deal with "economy cigarettes" sold by competitors. Robertson, stupra note 36, at 31.32 .

44. See p. 1513. This calculation does not include wholesaler and retailer margitus because these men are unlikely to be willing to give up much of their margins to protect one brand over another as long as total sales are not immediately threatencd. 
and consequently less costly than the inconvenience of collecting it. Thus, all but the smallest tar and nicotine taxes are not likely to be fully absorbed, except possibly as a temporary measure.

The industry's third option, increasing prices across the board, is a more likely response. Because the habitual smoker's demand is highly inelastic, tobacco distributors and retailers can raise prices generally, disregarding varying tax rates, without losing significant sales volume. They are somewhat limited in so doing, however, by their competition with one another and their fear of smuggling. Because this response affects the tax's incentives in approximately the same manner as the second response, absorption, they can be discussed together.

Even if the retail prices do not fully reflect the tax's differing treatment of various brands because of industry absorption or general price increases, the same benign cycle of vendor/consumer shifts towards low tar and nicotine cigarettes should occur just as if the differences were passed on to the consumer. Although the tax's direct impact on the consumer would be reduced, it will be increased vis-a-vis the industry. If the tax on a high tar and nicotine brand is absorbed, the profitability of that brand will suffer proportionately. Even if prices are raised across the board, losses on high tar and nicotine brands will be supported by the untaxed, low tar brands. In either case, the manufacturers and vendors would be given a most compelling reason to switch as quickly as possible into the more profitable, safer cigarettes. They could do so by developing new low tar brands, downgrading existing ones, and giving greater sales emphasis to their safer, more profitable untaxed brands. These efforts will in turn affect the smoking consumer.

This second, industry-led phase of the switching cycle will, however, be more difficult to start than the first for all but a federal tax. A single local or state tax is unlikely to affect enough of the market to force the manufacturers to change their marketing plans. However, a series of such taxes, either because of their cumulative effect or their trend-setting nature, should have sufficient impact to set the cycle in motion. ${ }^{45}$

But even in the short-run and without a major impact on the na-

45. After New York's tar and nicotine tax was enacted, the Philip Morris Company introduced "Marlboro Lights," a variant on their leading Marlboro brand vith tar and nicotine levels "lowered" below the city's cut-off points. This introduction of a variant on a major brand, instead of an entirely new name, was a departure from the industry norm. At the same time, American Brands introduced a conventional new low tar brand, "Lucky Ten." The introduction of these brands may have been callsed by" factors other than the New York tax, such as a growing consumer demand for low tar cigarettes as a result of government warnings. It seems probable, hovever, that the tax at least added to the already considerable "health issue" pressure on the industry; and possibly suggested a way to respond. 
tional market, absorption and across-the-board price increases will not necessarily enable established high tar and nicotine brands to main. tain their market share-the measure of success in the industry-in a community with a tar and nicotine tax. A local government anxious to ensure maximum local consumer switching may employ a number of methods to ensure that the tax's warning and incentive are not obscured: increasing the tax's differentials, regulating prices, and/ or generating publicity. Raising the tax differentials significantly, by far the most effective response, would encourage competition and reduce the number of cases in which it is less expensive to absorb the tax than to pass it on. Second, government could require that retail prices mirror distinctions made by the tax. A form of such price regulation is now in effect in many states for alcoholic beverages, an. other sumptuary item. The New York tar and nicotine ordinance tax specifically allows the city's Director of Finance to impose such controls. ${ }^{48}$ Lastly, government could itself publicize or require retailers to publicize the differing tax rates for each brand. ${ }^{47}$ Government could foster such awareness, for example, by causing differentcolored tax stamps to be applied to each pack depending on the rate paid. Such actions would increase consumer awareness of price (and health) differences among brands and would be consistent with the public health purpose of the tax.

Industry experience suggests that consumers will respond to such warnings and incentives, if they are also given an alternative that does not require them to stop smoking. In the 1930 's, smokers demonstrated that price does make a difference: The major national brands lost fifteen per cent of their sales to "economy brands" with lower prices but relatively little advertising. ${ }^{48}$ In the 1950 's and early 1960 's, smokers dramatically demonstrated that they will switch to safer cigarettes: Sales of non-filter cigarettes were halved between 1956 and 1967.49 The fact that cigarette consumers have previously demonstrated considerable sensitivity to price and some awareness of the health hazard ${ }^{50}$ certainly suggests that they will respond to the tar and nicotine tax's use of both factors together.

New York's experience seems to support this expectation. An analysis

46. Tar and Nicotine Ordinances, Local Law 34, 5 NEw YoRk CirY, N.Y., $\Lambda$ din. CoDE § D46.8.0 (Supp. 1971).

47. In spite of his authority to control prices, the Finance Administrator cliose to act initially to require only that all retailers post notices provided by the city explaining why and how much each brand is taxed. See The City Record, Nov. 30, 1971, at 5471, col. 2, and N.Y. Times, Dec. 24, 1971, at 7, col. 3.

48. Robertson, supra note 36 , at $29-34$.

49. See U.S. Dep't of Agriculture, June, 1970, at 9 Tobacco Situation.

50. See note 13 . 
of the tax receipts from the city's two cigarette taxes, the old fourcents-a-pack, flat-rate tax and the new tar and nicotine tax, suggests that there may have been a shift from taxed to exempt brands of approximately twelve to thirteen per cent of all cigarettes sold in the city. ${ }^{51}$ This estimate is especially encouraging as New York is a rather difficult test case: Even before the incentive tax was imposed the city had one of the highest per pack cigarette taxes in the country and consequently a major smuggling problem. ${ }^{52}$ While this means that the incentive differentials had to be greater than elsewhere to have the same impact on the city's inflated prices, the fear of encouraging even more smuggling led officials to impose small differentials of three and four cents. Although each retailer is required to post the amount each brand is taxed and why, most retail prices in the city do not reflect the tax's low rates. ${ }^{53}$

The twelve to thirteen per cent estimate of consumer switching could be wrong for three reasons.

First, it is possible that the pretax distribution of brands sold in New York was different from the national mix used in calculating the shift. If New York consumers were already purchasing more low tar and nicotine brands than the national average, the shift estimate would be too high. Unfortunately there is almost no evidence available on this point.

Second, if the period of analysis coincided with a national trend away from high tar and nicotine brands, the twelve to thirteen per cent figure would also be overstating the impact of the tax. However, this was almost certainly not the case. The average tar and nicotine per cigarette consumed nationally during the period did

51. This estimate is computed by determining how many packs of cigarcttes actually passed through the city's tax mechanism by dividing total revenue from the old fourcents-a-pack flat-rate tax by four. Then, by taking the pretax proportion of total cigarette sales attributable to each level of tar and nicotinc, one can compute what the size of the new tax should be if no shifting had occurred. The average monthly revenuc from New York's tax has been 15.4 per cent below that figure. (The months of July; and August 1971 were excluded from this calculation beause the revenue generated in these months was temporarily depressed by administrative start-up problems.)

The difference would be explained if there had been a shift of 12.7 per cent of all cigarettes sold from high tar and nicotine to cxempt brands. This figure assumes that the ten per cent of cigarettes above only one of the two standards (and therefore taxed at only three cents) will be twice as likely to be switched to the zero cent rate as the seventy-five per cent of all brands (taxed at four cents) which are farther from the borderline. The monthly revenue figures were supplied by Mr. Peter Shalleck of the New York City Finance Administration, January and Junc, 1972.

52. See P. 1502.

53. The low tax differentials of three to four cents a pack allow many retailers to continue to charge one price for all brands. This presumably limits the tax's impact on the consumer. Indeed, if the tax had no impact, its failure might have been explained by the inadequacy of the incentive. Still, the failure of the tax's distinctions to be reflected fully in retail prices suggests that future taxes should have langer differentials. 
not decrease, it increased. 54 Thus, unless New York consumption was shifting against national trends for reasons other than the tax, the estimate seems to err on the side of being conservative, if it errs at all.

Third, New York's significant level of smuggling, about thirteen per cent of all cigarette sales in the city, ${ }^{55}$ may distort the calculations. ${ }^{56}$ Smugglers may prefer to sell high tar and nicotine brands because of the greater taxed-untaxed differential. If they were able to manipulate their market, this would create an exaggerated impression of shifting to untaxed brands in measurements based only on cigarettes actually taxed. But this danger seems limited. Therc was only about a two per cent increase in the volume of both smuggling and avoidance attributable to the tax over its first ten months. ${ }^{\text {of }}$ Moreover, the smugglers probably have to supply whatever brands

54. Revenue estimates based on the 1971.72 brand sales volume and tarenicotinc level figures are higher, not lower, than 1970-71. The average level of tar remaincd constant but the average level of nicotine increased significantly. Maxwell, Cigaretle Scoreboard, Barrons, Dec., 1971; Feb., 1972; and the Apr., 1972, F.T.C. Tar and Nico. tine Measurements.

55. Although the city has 3.8 per cent of the nation's population, its traditional four-cents-a-pack flat-rate cigarette tax is collected on only 16.5 billion cigarettes, 3.3 per cent of national sales. The assumption that the difference is smuggled is stipported by the fact that urban centers have the highest proportion of smokers, followed by suburbs, and then rural areas. DieHL, supra note 8 , at 122.23,

56. The calculation of twelve to thirteen per cent indicates what is happening among those who buy from legitimate dealers. Since those who buy from both legitimate and illegal sources will almost always buy the same brand in both places, the trend observed among sales by legitimate dealers may also be reflected in the black market. On the other hand, some smokers of brands now subject to the new tax may have sought out bootleg sources to avoid the tax. This last possibility is somewhat tempered by the fact that cigarette smugglers pass on to their customers only part of the difference between their purchase supply cost and legitimate retail prices. Thus, some New York smuggling operations are reported to be charging a higher price for cigarettes subject to the tar and nicotine tax than for those that are exempt. Interview with Mr. Morris Weintraub, Managing Director, Wholesale Tobacco Distributors of New York, Inc., Dec. 23, 1971 .

57. The two per cent increase attributed to the tar and nicotine tax is derived ats follows. For the first ten months of the fiscal year 1971-72, the total rise in smuggling and avoidance for New York was 3.8 per cent. This 3.8 per cent figure is computed by comparing the average monthly tax receipts for the first ten months of the fiscal year 1971-72 with the average receipts for 1968-71. The tax receipt data were supplicd by Mr. Peter Shalleck, New York City Finance Administration. During the perlod 1968-71, average per capita consumption remained virtually static: 2640 cigarettes per capita in 1968 vs. 2648 cigarettes in 1971. Tobacco TAx CounciL, supra note 10, at $\mathrm{g}$. Since the city's population has also remained static during 1968.71 , the 3.8 per cent smuggling and avoidance estimate should not be increased by any incrcasc in total national sales.

However, it would be wrong to attribute the 3.8 per cent increase solely to the tar and nicotine tax. On June 1, 1971, the sales tax was raised one per cent-which is equivalent to .5 to .6 cents a pack. The tar and nicotine tax had an averagc initial impact of 3.5 cents a pack. The state cigarette tax was then increased thrce cents a pack in February 1972. Although one can see a further drop in taxed sales after I'cb. ruary 1972 , it is extremely difficult to disentangle the effects of the different taxes directly. However, a reasonable assumption is that the tar and nicotinc tax causcd only as much of the loss as its portion of the increased tax burden, roughly half the 3.8 per cent loss. 
their customers demand. ${ }^{58}$ Finally the smugglers' response to the tax actually seems quite different; they are reported to be charging higher prices for brands subject to the tax. ${ }^{50}$ Thus, the impact of the tax's incentives seems not to be lost even on those who do not legally pay it.

While the twelve to thirteen per cent estimate may require some modifications, the revenue figures do suggest that the tar and nicotine tax has had at least some of the public health impact intended.

\section{The Tar and Nicotine Tax as a Source of Revenue}

For those who envision the tar and nicotine incentive tax solely as a revenue raiser as well as a regulatory measure, a potential objection to the tax is that it might not be dependable or sustained as a source of funds. Public officials may be unnerved because revenue will decline to the extent the tax actually lowers tar and nicotine consumption. They should not be: The amount of revenue to be expected from the tax can be predicted ${ }^{00}$ and adjusted quite easily.

Exact predictions are, of course, impossible because the responses of the tobacco industry and its customers to a unique, new stimulus are unknown. Predicting state or local revenue is even more uncertain because of smuggling and the differing sizes of the jurisdictions. But these uncertainties are largely a function of the tax's novelty: Switching by consumers in response to the tax will probably be concentrated in its first year or so. Thereafter, revenue should hold relatively constant, and reliable future estimates can be made from this initial experience. Even now, with only New York's limited experience available, revenue calculations made from relatively extreme assumptions establish a narrow range of likely results for a national tax. The following table shows the probable revenue that

58. Smugglers would have to increase the number of high-tar and nicotine cigarctes sold dramatically to account for the switching reflected in the city's revenue figures. Even if all the increase in smuggling were in high-content brands, and if all prior bootleg sales of low-content brands were replaced with high-content sales, the increase in high tar and nicotine cigarettes sold necessary to account for New York's switching could be reached only if prior bootlegged sales had an exceptionally large proportion of lowcontent brands, a rather unlikely eventuality.

59. Interview with Mr. Morris Weintraub, and Mr. Alan Weintraub of the Cigarette Merchandisers' Association (New York), December, 1971.

60. The McKinsey estimate of the annual revenue that New York City could expeet from its tar and nicotine tax was $\$ 22.6$ million. Although revenue for the first six months was running at a $\$ 22.7$ million annual rate, the slow start up in July and August, added smuggling and avoidance caused by other increases in the local cigarette tax burden, and some continuing switching to low tar brands may push actual first year revenue slightly below \$22.6 million. 
would be generated in the first year of a national tar and nicotine tax of four different rates: ${ }^{61}$

Estimated Revenue from a National Tar and Nicotine Tax

$\begin{array}{lcccc} & \text { Low } & \begin{array}{c}\text { National Revenue } \\ \text { (Millions of } \\ \text { Dollars) } \\ \text { Medium }\end{array} & \begin{array}{c}\text { Medium Revenue per } \\ \text { Million Population } \\ \text { (Millions of } \\ \text { Pollars) }\end{array} \\ \text { 0, 2, 3 cents } & 606 & 639 & 672 & 3.2 \\ 0,3,4 \text { cents } & 778 & 839 & 901 & 4.2 \\ \mathbf{0 , 5} \text {, 6 cents } & 1,116 & 1,239 & 1,352 & 6.2 \\ \mathbf{0 , 9}, 10 \text { cents } & 1,691 & 1,978 & 2,205 & 9.9\end{array}$

Estimates of the revenue a local community could expect from the tax can be roughly calculated as a proportional share of the nattional estimates equal to its per cent of the national populition. This initial calculation should be refined by accounting for smuggling and avoidance likely to be associated with the particular locality. ${ }^{62}$ Areas with relatively low retail prices will generally gain sales and tax revenue from high price areas with the size of the increase depending on the size of the price differential and the distance from the other jurisdictions. ${ }^{03}$ There may also be minor variations in revenue due to varying smoking habits.

However, even if the tax produces less revenue than expected, its rates can always be increased. Thus, even a local government with an

61. These estimates are all based on the assumption that tax liability would result, as in the case of New York, at cut-off points of 17 milligrams of tar and 1.1 milligrams of nicotine per cigarette. A midrange revente estimate for the first ycar of a national tar and nicotine tax with rates of 0,3 and 4 cents a pack is $\$ 839$ million; a similar estimate for rates of 0,9 and 10 cents a pack is $\$ 1,978$ million. $\Lambda$ sstuming that total demand for cigarettes remained unchanged, each additional penny added to the cxisting flat-rate federal tax of 8 cents per pack would rate $\$ 255.8$ million in new revenuc a year. Tobacco Tax Council, The Tax Burden on Tolsacco 6 (1970).

62. Smuggling and evasion can be estimated from past increases in cigarctte tax rates, although a tar and nicotine tax should lead to somewhat less smuggling than an equivalent flat-rate cigarete tax as it would provide smokers with the legal alternative of avoiding the tax by switching to low tar and nicotine cigarettes. For a discussion of increases in cigarette tax rates see BUREAU OF THE CENSUS, U.S. DEl'T OF COMMERCL, State Gov't Finances in 1970 (1970). Given past experience, revenue cstimates call as. sume that additional tobacco taxes will not lead to a rapid, lasting drop in cigarctte consumption although it may help discourage some people from starting the habit and a small number from continuing. Cf. Ciry and Counry of Denver, Financing Mu. Nicipal Government in Denver (1955); Hamovitch, Sales Taxation: An Analysis of the Effects of Rate Increases in Two Contrasting Cases, 19 NAT'L TAx J. 411 (1966); Mc. Allister, The Border Tax Problem in Washington, 16 NAT'L TAX J. 362 (1961).

63. This effect tends to be hidden because the areas with highest cigarette retail prices (and taxes) are generally urban, and city-dwellers smoke more on average than non-urban Americans. 
acute smuggling problem can assure itself of the revenue it needs. In New York, which probably has the worst smuggling problem in the country, adding a penny a pack to the rate, a twenty-five per cent increase, probably would not have increased smuggling and avoidance significantly: When new cigarette taxes totalling seven cents a pack were imposed in 1971-72, such losses increased only about four per cent. ${ }^{64}$

In sum, a tar and nicotine tax should provide a significant and reliable source of new revenue, as well as an important means of cutting public health costs.

\section{The Administration of $a$ Tar and Nicotine Tax}

Compared to most taxes, let alone direct controls, a tar and nicotine tax is easy and inexpensive to collect. All cigarettes sold in the country are now subject to state as well as federal flat-rate excise taxes. Consequently, any new or increased cigarette taxes can "piggyback" on existing collection mechanisms. ${ }^{65}$ The usual procedure is for each pack sold to be stamped by a licensed tax agent who is thereby responsible for collecting the tax and who is paid a small percentage of collections for his services. A tar and nicotine tax can be collected by these agents in the same way as the present flat-rate taxes.

A tar and nicotine tax would require the agents to take one additional simple step. Before stamping each pack in a crate, they would have to determine the appropriate tax by checking the brand on a one-page card issued by the Federal Trade Commission, listing each brand and type of cigarette by tar and nicotine content. ${ }^{\circ 0}$ Of course, when the periodic FTC tests indicate a change in a cigarette's tar and/or nicotine content, tax liability would also change.

A tar and nicotine tax would, however, create serious problems for vending machine companies. ${ }^{67}$ Although modern vending equipment can handle four prices, most older machines can deal with only

61. See note 57 supra.

65. State governments would have no trouble in piggy-backing on their orn taxes. Local governments without a cigarette tax of their own would, however, probably have to work out an agreement with their state's tax administration to permit joint stamps and common licensing of agents.

66. Federal Trade Comm'n, Tax and Nicotine Content of Cigarettes (issucd periodically).

67. For example, some of the older machines located in markets like New York with unusually high prices will have trouble moving to prices of sixty-five or seventy cents a pack because at least four coins will be required for each transaction. Telephone interviews with Mr. Alan Weintraub, The Cigarette Merchandisers' Association (Ncw York) and Mr. Classano, Rowe International Corporation, vending machine manufacturers and operators, February 1971. 
two or three, ${ }^{68}$ and some of the oldest can sell at only one..$^{00} \mathrm{~A}$ tar and nicotine tax with its different rates would force many owners to choose between absorbing the tax on some cigarettes or charging more for all. ${ }^{70}$ Even those who could adjust their machines to charge several different rates would face extra conversion, clerical and serv. ice costs. Further, because the machines record only the total number of packs sold and because the operating companies have not usually maintained inventory control by brand, some service men might possibly report more low-priced sales than actually occurred and pocket the difference. ${ }^{71}$ Moreover, if the price differences were not in nickel or dime increments, none of the machines could account exactly for the tax. Periodic readjustments in the tax liability of various brands, required in response to new FTC tar and nicotine ratings, would create a further small, ${ }^{72}$ but periodic, cost to vending machine operators. The vending machine industry's difficulties would be substantially increased if it were legally required to charge prices reflecting a tar and nicotine tax's different rates. Many of the old machines belonging to small businessmen and clubs could not comply and would have to be put out of operation unless they were exempted from the requirement. However, governments anxious to have retail prices reflect differences in the tax rates but wishing to avoid placing these extra burdens on vending machine operators, could exempt them from the regulation requiring retail prices to reflect the tax's differentials while

68. In New York City, only half the cigarette vending machines can handle threc or more prices; an additional forty per cent are able to charge two different prices, Telephone interviews with twenty vending machine companies in the mctropolitan area, February 1971.

69. The old one-price machines are owned and operated primarily by clubs, restatl. rants, and small stores. Increased price variation would reduce the value of these older machines somewhat, thereby hurting the small businessmen.

70. In either case the vending machine company would find sales of low tar and nicotine cigarettes more profitable than those taxed at a higher rate, which should lead operators to seek to sell a larger percentage of low tar and nicotine cigarcttes.

71. Vending. machine operators in New York City have experienced a short-term conversion problem, a permanent increase in clerical costs, a new fall in sales due to smuggling, and some problems of theft by servicemen as a result of the tar and nicotinc tax. (Correspondence from Cigarette Merchandisers' Association (New York) to Richard Lewisohn, Finance Administrator, and Mr. Harry Katz, Assistant Finance Administrator, July to December 1971; interview with Mr. Morris Weintraub and Mr. Alan Wcintratub of the Association and the Wholesale Tobacco Distributors of New York, December 28 , 1971.) One of the largest vending companies, Paramount, claims a conversion expense of $\$ 16,000$. However serious the costs of conversion and increased record kecping, the vend. ing machine companies' chief complaint is a drop in sales allegedly ranging top to four. teen per cent. (Correspondence between vending machine operating companies, November and December 1971.) The vending companies affected attribute these losses to smuggling, although the number of packs actually taxed declined only 2.8 per cent following the imposition of the tar and nicotine tax and increased state sales tax.

72. This cost would be substantially smaller than that of initially adjusting to several different rates because it could be accomplished primarily by shuffling brands in thic columns of the machines. 
still insisting that they post a notice on each machine informing the public how much tax was levied on each brand on sale in the machine. Alternatively, they could levy an extra tax on those choosing not to conform with the requirement.

Cigarette bootlegging is a serious problem for local and state governments with relatively high tobacco taxes. ${ }^{73}$ Obviously, extensive smuggling created by a wide range of price differentials between jurisdictions is highly undesirable: It deprives both the government and legitimate dealers of needed revenues; it creates a strong incentive for businessmen and enforcement officials to share in the large profits available from smuggling; and it provides a major source of income for organized crime. ${ }^{74}$ The possibility of smuggling is thus a strong argument against high tax localities increasing their rates still further.

However, this argument has definite limits. The fear of smuggling need not inhibit either the federal government or local governments with relatively low tobacco taxes from increasing the taxes on cigarettes. Furthermore, significant differentials can be created without raising the average price if existing cigarette taxes on low tar brands are reduced, a move which need not produce a net revenue loss if the tax on high brands were simultaneously increased.

Nevertheless, smuggling remains a significant constraint for some communities. Under a tar and nicotine tax, the amount of smuggling (and switching) should increase with the proportion of all cigarette brands taxed at the higher rate, as well as with the size of the incremental tax. As more brands with reduced tar and nicotine levels and a lower tax liability become available, the incentive to smuggle will be more than proportionately reduced. ${ }^{55}$

An additional problem, especially for smaller local governments, is tax avoidance through extra-jurisdictional purchases. Like smuggling, the effect of this avoidance will depend upon the rate of the tax relative to the taxes of the surrounding areas and the distance

73. See, e.g., p. 1502 supra.

74. D. Cressey, TheFt of a Nation 245 (1969); R. SAlerio \& J. Touphiss, Tile Crime Confederation 38, 158 (1969); letter from Governor Nelson Rockefelier of New York to Congressman Emanuel Celler, Jan. 23, 1970, stating, "[C]igarette smuggling has proved to be a highly profitable source of income for elements of organized crime . . .."

75. The tobacco industry in areas subject to smuggling could minimize crasion under a tar and nicotine tax by not raising cigarette prices on cigarettes not subject to new taxes. The industry campaigned vigorously against New York's new tax on the grounds that the tax increase would encourage smuggling, an entirely legitimate argu. ment. However, the industry's initial effort to raise prices five cents across the board once the tax was enacted, even on those cigarettes not subject to the tar and nicotine tax at all, is not consistent with its sense of urgency and commitment in dealing with the problem. 
which local citizens must travel for lower taxed brands. Instead of going to the trouble of buying high tar cigarettes in another jurisdiction, at least some consumers, especially new ones, will probably switch to a safer, cheaper brand. ${ }^{\text {it }}$

In high-tax jurisdictions existing revenue losses from smuggling 77 and other forms of cigarette tax evasion might be reduced with a stronger law enforcement effort. In New York, for example, the current level of enforcement is clearly inadequate. The city's Cigarette Tax Enforcement Unit operates on an unvarying nine-to-five, noweekend work schedule, a fact presumably well known to the smugglers. ${ }^{78}$ The increased temptation to smuggle created by high-tax local governments increasing their taxes on cigarettes might well be offset by increased and more effective law enforcement.

\section{E. The Equity of a Tar and Nicotine Tax}

Any increase in cigarette taxes, regardless of form, will be somewhat regressive. Although the middle class and the wealthy spend more on tobacco than the poor, this expenditure is a smaller pro. portion of their income. ${ }^{70}$ However, a tar and nicotine tax should be less regressive than a customary flat-rate tax: The poor consumer can escape the tax entirely by switching to low tar brands, and if the tax does force him to switch, the net result of health cost savings might even prove quite progressive.

In sum, a tar and nicotine tax gives a government an effective tool for inducing reduction in tar and nicotine levels, while providing a

76. Although most smokers have strong short-term brand loyalty, the typical smoker changes brand allegiance periodically. The new federal ban on cigarctic broudcist advertising may weaken brand loyalties. Brand market shares have, in any case, flitc. tuated widely over time (STANDARD \& POOR's, supra note 15, at 106.08). However, short. term brand loyalty for cigarettes is quite high. (See Consumer Dynamics in the Super. market, at Progressive Grocer K89 (1966).)

77. Mr. Albert Sohn of the New York State Commission of Investigation cstimates that the State and City of New York lost $\$ 342$ million in revenues as a result of cigarette smuggling over the last six years. The New York Post, Jan. 18, 1972, at 4 , col. 2.

78. Testimony of Mr. Beverly Starkey, chief of the New York Special Investigating Division and Mr. Joseph Haggerty, head of the Cigarette Tax Enforcement Unit, beforc the New York State Investigation Commission, Jan. 19, 1972. Cigarette smuggling in New York is a misdemeanor, regardless of the volume smuggled. However, the civil tax penalty is stiff- $\$ 100.00$ a carton plus fifty per cent of the unpaid cigarette tax.

79. Any increase in cigarette taxes, regardless of its form, will have to meet the objection that such an increase is regressive. The poor and near-poor begin smoking at an earlier age and smoke more than the more wealthy and better educated. $\Lambda$. PKESI', Public Finance 370 (1963); Heath, 101 A.M.A. Arch. Internal Medicine 377 (1958); McArthur, Waldron \& Dickinson, The Psychology of Smoking, 56 J. Amokmal \& SocinL Psychology 267, 267-75 (1958); Salber \& MacMahon, Cigarette Smoking Among High School Students Related to Social Class and Parental Smoking Habits, 51 AM. J. Puutic HEALTH 1780 (1961). Smokers with annual incomes of less than $\$ 6,000$ spend a roughly constant proportion of their income on tobacco; wealthier smokers spend proportionatcly less. DienL, supra note 8 , at 122-23. 
reliable source of revenue. Although a flat-rate tax poses fewer administrative problems, a tar and nicotine tax, which in any case uses the same collection mechanism as the flat-rate tax, is quite administrable. However, smuggling and extrajurisdictional purchases may lessen the effectiveness of a tar and nicotine tax, and the tax, like all excise taxes, may be somewhat regressive.

\section{Engineering an Effective Tax}

Designing the most effective tar and nicotine tax involves four considerations: the limitation of the tax to cigarettes, the best milligram cutoff points for tar and nicotine liability, the optimal rate structure, and the level of government imposing the tax.

\section{A. Taxing Cigarettes Only}

Health and administrative reasons dictate that the tax be restricted to cigarettes. In terms of health, pipe- and cigar-smoking entail ingesting a very much smaller quantity of tar and nicotine. Thus, while cigarettes comprise roughly eighty per cent of all tobacco sales, they are the cause of ninety-six per cent of all tobacco related deaths. ${ }^{80}$ Therefore medical authorities argue that cigars and pipes should be given relative encouragement. ${ }^{81}$ But cigar and pipe smokers are substantially less likely to be regular smokers and are much more likely to switch both smoking mode and brand than cigarette smokers. ${ }^{82}$ The

80. Bell \& Laing, Statistical Analysis of Morlality Rates of Cigarctle, Pife and Cigar Smokets, 100 Canadian Medical Ass's J. 806 (1969).

81. Cigar and pipe smoke is so heavy and alkaline that inhaling is unpleasant and therefore rare. In early 1971, the Royal College of Physicians (London) reported that:

The (resulting) remarkable disparity of risk between smokers of cigarettes and smokers of pipes and cigars suggests that much saving of life and health might be achieved if cigarette smokers were to change to pipes and cigars.

Royal College, supra note 7, at 131 . To encourage such switching, the Rojal College advocated tax differentials. In fact, such differentials already exist in the United States: For example, the federal government taxes cigars with the same tobacco content as cigarettes at $\$ 0.75$ a thousand rate instead of the $\$ 4.00$ a thousand rate applied to cigarettes. 26 U.S.C. 5701 (a)(b) (1954).

No study has been undertaken as of this date which has compared the danger of smoking small cigars to that of smoking cigarettes. Telephone interviews with Dr. George Moore, Roswell Park Memorial Institute; Dr. Woodward, Department of Agriculture (Philadelphia Laboratory); Dr. Don Schoplind, National Clearinghouse for Smoking and Health; and Mr. Brauninger, Federal Trade Commission, February 8, 1971. Dr. Moore suggested that small cigars were probably less dangerous than cigarettes because they are likely to be inhaled less frequently, and because fewer are fikely to be consumed by the average smoker on any given day.

However, even so, the pipe smoker has a mortality rate cleven per cent higher than nonsmokers. Garfinkel, The Association Between Cigarette Smohing and Coronary Heart Disease and Other Vascular Diseases, 44 BuLL. N.Y. ACAD. MED. 1496 (1969). See also SURGEON GENERAL'S REPORT 233 (1964).

82. See, e.g., TIME Marketing and Researci Report No. 1606 (1970). 
cigar industry has consequently found it difficult to pass increased costs on to the consumer. ${ }^{83}$ Thus, tax increases on cigars and pipe tobacco would undoubtedly have the opposite effect of accelerating their persistent long-term loss of tobacco market share.

Administratively, it is easier to tax only cigarettes because a new cigarette tax can be collected through mechanisms already established for collecting the current cigarette taxes, whereas taxes on other forms of tobacco would generally require new collection procedures. Moreover, Federal Trade Commission tests of cigarette tar and nicotine content would provide a dependable, generally accepted, and no-cost method of determining the liability of particular brands and types of cigarettes. To extend a tar and nicotine tax to cigars and pipe to. bacco, however, government would have to develop and implement a measuring and testing system for a large number of low-volume tobacco products. Since relatively little research has been conducted on cigar and pipe smoking, determining appropriate standards would also be a problem. ${ }^{84}$

\section{B. Delimiting Tax Liability}

Since a small amount of tar or nicotine is not "safe," but only less harmful than a larger dosage, there are no clear, medically determined cutoff points for tax liability. Consequently, the points at which tax liability occur should be selected so as to produce the largest and most rapid reduction in both tar and nicotine levels. As manufacturers can reduce tar without altering nicotine content and vice versa, ${ }^{85}$ a government seeking to diminish the consumption of both elements should base tax liability on both.

More than one cutoff point for one or both substances can exist, and government could create a wide range of corresponding tax rates. It would probably be desirable, for example, to offer an additional incentive for the small class of cigarettes with exceptionally low tar and

83. Annual Reports compiled by Cigar Manufacturers Association of Amcrica and First National City Bank, Letter of Apr., 1970.

84. Moreover, past experience with cigar and manufactured tobacco taxes has bectl discouraging. Although all the states, and at least 272 localities tax cigarettes, only twenty-two states and seventeen localities tax other tobacco products. Congress repcalcd the tax on manufactured tobacco in 1965, primarily because it was considered especially regressive. New York State imposed a fifteen per cent tax on cigars and pipe tobaceo in 1959, but the tax was repealed in 1961, after massive smuggling and mail order evasion, a drop in retail sales of twenty-five to thirty per cent, declines in tobacconists sales of other goods, and spirited opposition from the retailers supported by the press. See N.Y. Times, Nov. 29, 1959, \$ 3 at 1, col. 8; June 15, 1960, § 4, at 1, col. 5.

85. The Federal Trade Commission's Tar and Nicotine Content of Cigaretles, which is issued periodically, shows variations in the relationship between the tar and nicotine levels in individual brands from November, 1970, to April, 1972. 
nicotine levels. ${ }^{86}$ However, New York's experience with its 0, 3, and 4 cent tax indicates that to achieve adequate impact at the retail level, each tax increment should ideally be at least a nickel; and this factor clearly limits the number of levels most governments will be able to impose.

The determination of the exact cutoff points for tar and nicotine involves an inevitable tradeoff. When the level of tar and nicotine subject to the tax is lowered, more smokers and brands are affected by the monetary incentive and more revenue is gained. On the other hand, when the level of taxable tar and nicotine is raised, more brands are left untaxed, the consumer has a greater choice of brands to switch to, and the taxed manufacturer must confront a greater number of untaxed competitive brands. An additional crucial consideration is that assuming manufacturers believe that lowering a brand's tar and nicotine levels a great deal would undermine brand loyalty, the incentives for manufacturer change created by a variable tax would be greatest on brands just above the cutoff points. ${ }^{87}$ From the standpoint of manufacturer incentive, the cutoff points should thus be just below the levels contained in a large number of cigarette brands. Presently, a group of over sixty per cent of all cigarettes exists within a narrow range just above 17.0 milligrams of tar per cigarette and 1.1 milligrams of nicotine per cigarette..$^{88}$

More specifically, a tar cutoff point between 17 and 18 milligrams or 18 and 19 milligrams, and a nicotine cutoff point between 1.1 and 1.2 milligrams or 1.2 and 1.3 milligrams appears to maximize the tax's impact. ${ }^{89}$ While any other point or combination of points

86. Providing special reductions or exemptions from existing flat-rate taxes as well as from the extra charges of a tar and nicotine tax for the small number of cigarcttes with exceptionally low tar and nicotine counts-e.g., those with less than 10 mgs. of tar and $0.6 \mathrm{mgs}$. of nicotine per cigarette-would be $\mathrm{a}$ valuable refinement of the incentive structure that would involve so little revenue loss that it might be acceptable even to governments giving high priority to the goal of revenue generation. Providing this additional incentive would underline the tax's public health objective, thercby increasing its potential educational impact.

87. This consideration is important because as the number of consumers shifting from a taxed-brand decreases, the manufacturer is less likely to alter the tar and nicotine content of his brand for fear of jeopardizing his remaining market. Hoviever, if he can easily get the tar and nicotine content of his brand below the cut-off points, even a slight decrease in his market might push him to avoid the tax, thereby causing an involuntary switch by his remaining consumer market.

88. McKinsey compilation on file with the Yale Law Jourmal, originally one part of the data and analyses prepared for New York City.

89. In a range of ten to thirty milligrams per cigarette of tar, sixty-three per cent of all cigarettes produced fall within the narrow band of eighteen through trienty milligrams. The next largest such three milligram grouping would be ninetcen through twenty-one milligrams, which accounts for approximately forty-five per cent of all cigarettes produced. A tax cutoff between seventeen and eighteen milligrams or cightcen 
is possible and may become desirable as tar and nicotine levels shift, 17.0 milligrams of tar and 1.1 milligrams of nicotine per cigarette seem to be the most effective cutoff points now. These cutoff points provide more revenue than a higher cutoff would; ${ }^{00}$ they leave a larger number of cigarettes subject to the tax's incentives. Yet, whatever incentive impact they lose by leaving fewer brands tax-free for consumers to switch to they gain by having a larger number of cigarettes very close to the border thus enabling manufacturers to avoid the tax with relatively little effort. They are the cutoff points adopted by New York.

The tax rate could be increased if either or both of the two cutoff points is exceeded. Since tar and nicotine levels are usually closely related, ${ }^{, 1}$ cigarettes with both tar and nicotine levels above the cutoff points are likely to contain more tar and more nicotine than cigarettes with one of the elements above and the other below the cutoff. Consequently, higher tax rates are appropriate when both cutoff points are exceeded. This reasoning suggests a three-tier system of incremental taxation with low or no tax increase for cigarettes with tar and nico. tine content below both the cutoff points, and a sharp increase in tax liability if one cutoff point is exceeded, and another, smaller in. crement if both points are violated.

As switching takes place after the enactment of the tax, fewer and fewer cigarettes will be subject to the pull of the tax's incentives. Consequently government should probably plan to review the cutoffs periodically to determine whether they should be lowered to ensure that the tax's effectiveness is maintained. Such periodic, gradual lowering of the cutoff would maintain the tax's incentive impact at a high level, allow the industry to cut tar and nicotine gradually without disrupting brand loyalties, and provide a relatively steady flow of revenue from the tax despite steadily receding tar and nicotine levels.

and ninetcen milligrams therefore appears to be the point of maximum leverage, In a range of 1.0 to 1.8 milligrams of nicotine per cigarette, a pattern somewhat similar to that of tar content is apparent; sixty-seven per cent of all cigarettes fall in the 1.2 to 1.4 milligram band and seventy-three per cent in the 1.3 to 1.5 milligram band.

90. A seventeen milligrams of tar cutoff would yicld a local government approximately seventeen per cent more revenue than an cighteen milligram cutoff, assuming a four cent a pack rate for cigarettes above the standard and the probable switching as a result of the tax.

A 1.1 milligram per cigarette cutoff for nicotine would yicld approximately threc per cent more revenue than a cutoff of 1.2 milligrams assuming a four cents a pack ratc and estimated switching (based on New York City's experience) as a result of the tax.

91. McKinsey calculations based on FEDERAL TRADE COMM'N, TAR AND Nicotine CON. TENT OF Cigarettes, November, 1970, April, 1972; Maxwell, Cigarette Scorebox, Barkons (Fall 1970). 


\section{Determining the Tax Rates}

The tax rates applied to different brands of cigarettes can be varied depending on their tar and nicotine content either by rearranging existing taxes or by simply increasing the rates applied to the high tar and nicotine brands. Given the importance of significant differences between the tax rates applied to cigarettes falling on different sides of the tar and nicotine cutoff points, government could ideally employ both means.

However, governments are much more likely simply to increase the rates applicable to high tar brands. How big should these additional levies be? The first problem is to determine the minimal selective increase in the tax necessary. If there are to be three different tax levels $(0,1$, and 2 cents a pack), cigarettes above both cutoffs must be taxed at least two cents more than untaxed brands. In terms of the manufacturers' ability to absorb the tax, a two cent tax would approximately halve average profits, a powerful incentive. This estimate is based on the fact that while the historical profit margin is approximately two cents, ${ }^{92}$ any tax absorbed would necessarily result in a federal tax savings of approximately one-half (48\%). Thus, absorbing a four-centa-pack increase would theoretically wipe out all profit. However, even four cents may somewhat underestimate the tax necessary to insure against manufacturer absorption of the tax. Manufacturers could help cover losses on high tar brands with profits from other untaxed brands, although this is not likely to continue for long. It is somewhat more likely that losses in some local markets where a brand is subject to the tax could be covered by profits from the rest of the market, though this would not be possible if the tax were national and would become increasingly difficult as more and more governments enacted similar taxes. Moreover, to the extent that the high tar and nicotine tobaccos are generally the least costly, profit margins on cigarettes with cheaper tobacco may be higher than the industry average, thus allowing even more absorption. Finally, although wholesalers and retailers have no interest in protecting sales of one brand against another, they may help manufacturers absorb at least small tax differences both as a matter of industry solidarity and, more importantly, as a means of keeping their record-keeping and sales process simple.

Another sort of minimum rate is determined by the inability of vending machines to handle differentials smaller than a nickel. Thus,

92. STANDARd \& POOR's, supra note 15, at T114 (1970). However, company profit margins vary widely. 
differentials of at least five cents, preferably ten cents a pack arc desirable to ensure that retail prices generally reflect the tax.

In contrast to the question of a minimum tax rate, it is not clear that there is a ceiling above which tax rates should not rise. The chief limiting factor for local and state jurisdictions is the fear of smuggling. This restraint applies especially to those localities that already have relatively high cigarette taxes. Thus, for example, New York City felt it could not impose new cigarette taxes much over four cents a pack..$^{93}$ Within the range established by these minimums and perceived maximum rates, governments will probably set rates primarily in light of their revenue needs and the importance they attribute to their public health objectives.

Thus the most promising combination of cutoffs and rates ap. pears to be a three-tier system: The eighty per cent of all cigarettes with more than 17.0 milligrams of tar and 1.1 milligrams of nicotine would be taxed at the highest rate; the nine per cent that exceed only one standard would be taxed at a slightly lower rate; and the eleven per cent below both cutoffs would not be taxed at all. The rate applied to double violators must be at least two cents and should be more than four or five cents a pack.

\section{Level of Government}

While a tar and nicotine tax could be adopted by any level of government, New York's reluctance to raise its rates above three and four cents a pack for fear of additional smuggling suggests that the level of government does make a difference. In contrast to New York, the federal government could impose a national tar and nicotine tax with little or no concern for smuggling. ${ }^{04}$

Particular local conditions as well as the size of the jurisdiction must also be considered. Thus, for example, state and local governments with relatively low tobacco taxes should be able to impose stiff new tar and nicotine taxes without stimulating a flow of smuggled cigarettes into their jurisdictions. Moreover, new taxes in such areas should reduce local sales to smugglers. Increases in cigarettc taxation in low-rate jurisdictions would also allow new cigarette im.

93. When enacted, New York's tar and nicotine tax made the city cigarette taxes the highest in the nation. Nevertheless, fourteen states, including all of New York State's immediate neighbors, still had higher ratios of tax to average retail price. Based on comparisons made from Commerce Clearing House, State Tax Reporter on state tax rates.

94. For much the same reasons only the federal government would find it casier to implement selective prohibition than local governments subject to smuggling. 
posts in high-tax areas without an increase in smuggling over present levels.

Another local condition that must be weighed in designing any new cigarette tax is the proportion of the population within the jurisdiction that commutes to or from other jurisdictions regularly. If it is a significant percentage, revenue calculations should be lowered to account for "avoidance," a tendency to buy more often in the nearby low tax areas. Avoidance is more likely to be a problem for New York, for example, than for other areas. However, if avoidance is already occurring, incremental losses may well be small as in New York.95

The imposition of a tar and nicotine tax by a local or state government will have a much lower incentive effect on national cigarette manufacturers than would a national tax, or even a number of local and state taxes. The New York tax, for example, applies to only 3.3 per cent of the taxed cigarette sales in the nation. Mfanufacturers may be reluctant to make major product or marketing changes in response to special tax problems encountered in only a small part of their market.

The leverage local taxes can have on national producers should not, however, be underestimated. Even New York's small 3.3 per cent of national sales amounts to 16.5 billion cigarettes a year, hardly an insignificant market. Further, the warning effect of a tax varying by tar and nicotine content may be extended beyond a local jurisdiction by commuters, tourists, other visitors, and possibly the news media. Moreover, the impact of local taxes on the cigarette industry will be magnified if and to the extent that it appears to the industry that the tar and nicotine tax is becoming a national trend.

Even if the national manufacturers succeed in appearing to ignore the first few local governments' tar and nicotine taxes, ${ }^{00}$ these taxes will still give local cigarette customers an incentive to switch to safer brands, and any such switching will reduce the manufacturers' high tar and nicotine production. Because retail pricing decisions are made by a great number of local wholesalers and retailers, and because these dealers would have to pay the local taxes (at least initially) and then make the decision to absorb or pass the tax on, the manufac-

95. See p. 1502.

96. It is possible that the industry might seck to undercut the tar and nicotine tax innovation by making it seem ineffective. The industry has lobbicd against the tax vigorously thus far, clearly perceiving it as a threat. It could afford to do so, even in the face of steep local taxes, if a procedure for supporting local dealcrs vith resources from the rest of the industry-possibly analogous to the oil companies" support for local outlets during gasoline price wars-could be worked out. 
turers should find it difficult to orchestrate uniform pricing in the face of a differentiated tax. Moreover, local governments can choose from a wide range of steps, ranging from required notices to fixed prices, to ensure that local incentives are not lost.07

A national tar and nicotine tax could be collected from the manufacturers-unlike state and local taxes which can be collected only locally from wholesalers and retailers. A tax imposed on the manufacturer tends to pyramid, or grow as it is passed on through the chain of distribution. By contrast, a tax levied on one locality's merchants tends to be partially absorbed as some merchants try to avoid losing customers to neighboring communities by holding prices down. For both reasons a national tax would better serve the government's public health purposes, as it would create a bigger price advantagc for safer brands. Moreover, a tax collected from a few manufacturers is slightly easier to enforce than one collected locally-though this burden should not be overemphasized as there is almost no incremental cost to "piggybacking" either a state or local tar and nico. tine tax on current collection systems, which exist in all fifty states. ${ }^{08}$

Thus, the most desirable tar and nicotine tax would be a federal one. Its terms would not be constrained by smuggling and avoidance; it could not be ignored because it would affect the national market; and it could be easily collected directly from the manufacturers. However, the tax could still be effectively implemented by most states and local governments, especially those which are large, have relatively low existing taxes, and have a small percentage of commuters who travel to and from adjacent low tax areas.

\section{Conclusion}

Government can take a realistic step toward improving the public health by imposing a tar and nicotine tax. Recognizing the fact that most smokers are habitual and that it is therefore unrealistic to expect to reduce total consumption quickly, the tar and nicotine tax seeks to reduce the harmful elements in what is smoked. It divides high against low tar and nicotine brands and gains much of its effectiveness from the resulting competitive clash. It is a good sourcc of revenue and poses few administrative problems. It should give government the power to force a change in smoking patterns.00

\footnotetext{
97. See p. 1500.

98. See p. 1505.

99. Governments facing stiff citizen resistance to new taxes may find the dual health and revenue intent of the tar and nicotine tax a significant advantagc. In the words of one high New York City official, "Who can oppose a tax on cancer?"
} 


\section{The Yale Law Journal}

Volume 81, Number 8, July 1972

\section{Richard Blumenthal Editor-in-Chief}

Peter T. Grossi, Jr.
Execulive Editor

Gurt A. Hessler

ROBERT B. REICH

Charles L. Woltmann

Article Editors

RALPH R. ARDITI

Dean D. Aulick

Michael J. Bean

DANIEL J. BELLER

RICHARD A. BLOCK

ERIC J. Branfman

Michael J. Churgin

Michael M. Conway

KathleEN M. DoggetT

Peter H. Ehrenberg

ROBERT W. FISHER

GARY L. Fontana

BRUCE G. FreEDMAN

Donald J. FriedMaN

NANCY G. Garrison

FREDERICK T. GoldBERG

Steven R. Gross

TIMOTHY S. HARDY
Roger W. Fonseca

Gharles A. Goldmark

Henry B. Hansmann

Daniel J. Kornstein Jay E. Pownell

Note \& Comment Editors

Frederick K. Heller, JR. Peter M. HoffMan JAMES R. HUNTWORK STANLEY N. INGBER Randall K.C. KaU KENNETH M. KaUfMan Eugene A. Ludwig JOSEPH M. MALKIN JaMes T. MALysiak ROBERT B. MANN SaMUEL H. MAYS, JR. JOHN B. OAKLEY NEIL H. O'DONNELL Russell K. OsGOOD STEPHEN A. OXMLAN Samuel T. Perkins Robert C. Pozen LINDA L. RANDELL
Robert E. GirsoN Managing Editor

Nancy Y. Benivac Bool Reviews Edilor

\author{
ROBERT S. RAYMAAR \\ Peter L. Rossiter \\ Míchael L. Schler \\ Geoffrey B. Shieldos \\ LESLIE N. SILVERMIAN \\ ArTHUR J. Silverstein \\ PETER WV.SLY \\ AviaMr SOIFER \\ MIARK I. Sol.er \\ SidNey H. Stein \\ Alexander R. Sussmax \\ ROBERT M. SUSSMIAN \\ S. Mark Tuller \\ RICHARD J. UROWSKY \\ MARK L. WEISSLER \\ AlaA J. WILENSKY \\ JERALD L. TWILKERSON \\ JEFFREY I. ZUCKERMAN
}

Business Secretaries M. Olive Butrerfield, Pairela Willirott

Student Contributors to This Issue

Daniel J. Kornstein, Taps for the Real Catch-22

Peter L. Rossiter, The Nixon Busing Bills and Congressional Power

Randall K.G. Kau, Resale of Restricted Securities under SEC Rule 144

Peter M. Hoffman, Evolving Judicial Standards under the National Environmental Policy Act and the Challenge of the Alaska Pipeline 